\title{
Genetic diversity and association of motilin receptor gene between growth traits in
} Nigerian improved native chickens

${ }^{1}$ Gunn, H. H., ${ }^{1}$ Chimenem-Amadi, S. N., ${ }^{1}$ Oleforuh-Okoleh, V. U. and ${ }^{2}$ Agaviezor, B. O. ${ }^{\prime}$ Department of Animal Science, Rivers State University, Port Harcourt, Nigeria

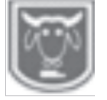

Abstract

${ }^{2}$ Department of Animal Science, University of Port Harcourt, Port Harcourt, Nigeria

Corresponding author: agaviezor@yahoo.com

The study was conducted to assess the genetic diversity and association of motilin receptor gene between growth traits in Nigerian improved native chickens by using 150 chickens of mixed sexes comprised of 50 naked neck, 50 Normal feathered and 50 Frizzled feathered. The birds were kept for 16 weeks during which feed and water were supplied ad libitum as well as medications/vaccinations. During this period, data on feed intake, feed conversion ratio, body weight, wing length, shank length, drumstick, body length, height at withers and breast girth were collected. Blood samples were collected for DNA extraction at the $16^{\text {th }}$ week. Polymerase Chain Reaction and sequencing was done. Data collected were subjected to Analysis of Variance (ANOVA). The results revealed $C>G$ mutation that was associated with the growth data. There was no significant $(p>0.05)$ difference between the haplotypes $(C C$ and $C G$ ) in feed intake although, CG haplotype (mutant gene) recorded the numerical higher value $(3584.00 \pm 11.96 \mathrm{~g})$. Significant effect $(p<0.05)$ was observed for feed conversion ratio with a range of $4.17 \pm 0.09$ in $C G$ to $4.22 \pm 0.11$ in $C C$. Body weight was also significant $(p<0.05)$ with values ranging from $1672.00 \pm 32.93 \mathrm{~g}$ in CC to $1954.00 \pm 29.45 \mathrm{~g}$ in CG. There was no significant ( $p>0.05)$ difference between the haplotype CC (normal) and haplotype $C G$ (mutant) for wing length, shank length, drumstick, body length, height at withers and breast girth. The highest estimates of evolutionary divergence between sequences (0.046) were observed between naked neck chickens and Normal feathered chickens. Normal feathered chicken had the highest within mean group genetic distance of 0.143. These results if properly harnessed could assist in the improvement of the Nigeria local chicken in terms of improved growth performance.

Keywords: Genetic diversity, motilin receptor gene, improved native chickens, Nigerian

\section{Diversité génétique et association du gène du récepteur motiline entre les caractères de croissance chez les poulets indigènes améliorés Nigérians}

\section{Résumé}

L'étude a été menée pour évaluer la diversité génétique et l'association du gène du récepteur de la motiline entre les traits de croissance chez des poulets indigènes améliorés nigérians en utilisant 150 poulets de sexes mixtes comprenant 50 à cou nu, 50 à plumes normales et 50 à plumes frisées. Les oiseaux ont été gardés pendant 16 semaines au cours desquelles de la nourriture et de l'eau ont été fournies ad libitum ainsi que des médicaments/vaccinations. Au cours de cette période, des données sur la prise alimentaire, le taux de conversion alimentaire, le poids corporel, la longueur des ailes, la longueur du jarret, le pilon, la longueur du corps, la hauteur au garrot et la circonférence de la poitrine ont été recueillies. Des échantillons de sang ont été prélevés pour l'extraction d'ADN à la l6e semaine. La réaction en chaîne par polymérase et le séquençage ont été effectués. Les données recueillies ont été soumises à une analyse de variance (ANOVA). Les résultats ont révélé une mutation 


\section{Genetic diversity and association of motilin receptor gene between growth traits}

$C>G$ associée aux données de croissance. Il n'y avait pas de différence significative $(p>0,05)$ entre les haplotypes (CC et $C G$ ) dans la prise alimentaire bien que l'haplotype CG (gène mutant) ait enregistré la valeur numérique la plus élevée (3584,00土11,96g). Un effet significatif $(p<0,05)$ a été observé pour le taux de conversion alimentaire avec une plage de 4,17 $\pm 0,09$ en $C G$ à 4,22 $\pm 0,11$ en $C C$. Le poids corporel était également significatif $(p<0,05)$ avec des valeurs allant de 1672,00 $\pm 32,93 \mathrm{~g}$ en CC à 1954,00 $\pm 29,45 \mathrm{~g}$ en CG. Il $n^{\prime} y$ avait pas de différence significative $(p>0,05)$ entre l'haplotype CC (normal) et l'haplotype CG (mutant) pour la longueur des ailes, la longueur du jarret, le pilon, la longueur du corps, la hauteur au garrot et la circonférence de la poitrine. Les estimations les plus élevées de divergence évolutive entre les séquences $(0,046)$ ont été observées entre les poulets à cou nu et les poulets à plumes normales. Le poulet à plumes normal avait la distance génétique la plus élevée au sein du groupe moyen de 0,143. Ces résultats, s'ils sont correctement exploités, pourraient contribuer à l'amélioration du poulet local du Nigeria en termes de performances de croissance améliorées.

Mots-clés : Diversité génétique, gène du récepteur motilin, poulets indigènes améliorés, nigérian

\section{Introduction}

Recently, there is a rising research into the association of candidate genes and performance traits in Nigerian native chickens with the efforts to improving the performance of these native chicken breeds (Agaviezor et al., 2018). The Nigerian local chicken are gradually becoming extinct, the village fowls normally found in the rural and suburban areas of Africa, is no longer a pure breed but rather the result of crossbreeding with various exotic stocks introduced into Africa (Ramlah, 2005). In village chicken production, uncontrolled mating is practiced, which is often modulated by indigenous breeding practices (Gondwe and Wollny, 2005). The use of molecular tools provides new insight into the genetic structure and diversity of indigenous chicken populations and associated genes will aids to test whether genotype frequencies or single-locus alleles differ among necked neck, normal and frizzle feather Nigerian local chick. Among the genes that are very important in the poultry industry is the motilin receptor gene. Motilin is an endogenous peptide that is released during the digestive cycle. Motilin stimulates the migrating motor complex III and accelerates gastric motility by binding to motilin receptors (Trudel et al.
2002). The motilin receptor is distributed widely in the digestive system and the central nervous system, with the greatest density in the alimentary canal (Ohshiro et al. 2008). Motilin receptor is located in a common region between $A D L 0198$ and $A B R 0287$ under the quantitative trait loci (QTL) peak adjacent to ABR0287 on chromosome 1 for body weight (Rikimaru et al., 2011). Previous work by Takahashi et al. (2014), showed an association between Motilin receptor haplotypes and growth traits in a population produced via the crossing between a low and high growth lines of Hinai-dori breed of Japan chicken. Several studies have explored the role of motilin and its receptors in the regulation of gastrointestinal motility and gastric emptying (Kitazawa et al. 2013). Yamamoto et al. (2008) reported that chicken motilin receptors affected gastrointestinal functions through an intracellular signaling pathway accompanied by an increase in $\mathrm{Ca}^{2+}$ levels during the pre- and post-hatch development phases. Takahashi et al. (2014) further noted that motilin gene may be a useful marker for improving growth and carcass traits in chicken. Furthermore, haplotype-assisted selection can serve as a potential useful approach to determine the association 


\section{Gunn, Chimenem-Amadi, Oleforuh-Okoleh and Agaviezor}

between haplotypes and growth traits in Nigerian local chickens. It is therefore important to investigate motilin receptor for growth traits in Nigerian local chickens since it has been reported that it plays a key role in appetite regulatory hormones and is a positional and functional candidate gene (Rosenfeld and Garthwaite, 1987).

\section{Materials and methods}

A total of 150 day old chicks of mixed sexes comprising 50 naked neck, 50 Normal feathered and 50 Frizzled feathered were obtained from the Federal University of Agriculture, Abeokuta, Nigeria. The birds were kept for 16 weeks. During the period of this experiment, the birds were fed with commercial diets according to their age. A starter diet (from 0-4 weeks of age) which contained $20 \%$ crude protein and $2800 \mathrm{kcal}$ of metabolizable energy (ME) and growers' diet (from 4-16weeks) containing 18.5\% crude protein and $2920 \mathrm{kcal}$ of ME. The birds had access to water and feed ad libitum. Each bird was tagged for proper identification. Routine medication and vaccination were also carried out when required. Daily data on feed intake and feed conversion ratio as well as weekly data on body weight, wing length, shank length, drumstick, body length, height at withers and breast girth were collected. About $3 \mathrm{~mL}$ of blood was collected from each bird from the wing vein in a $5 \mathrm{~mL}$ bottle gently mixed with the EDTA to prevent coagulation. The bottles were kept in an ice pack and transferred to the laboratory where they were preserved at $-4^{\circ} \mathrm{C}$ for DNA extraction. The DNA was extracted from the blood of naked neck, fizzled feather and normal feathered Nigerian local chicken, following the manufacturer's procedure as provided by "Quick DNA mini prep kit from Zymo Research, USA. The Thermo Scientific Nanodrop 2000, UV-VIS (ultravioletvisible) Spectrophotometer (Wilmington, Delaware, USA) was used to check the concentration and quality of the isolated DNA. Polymerase Chain Reaction (PCR) was carried out using $2.5 \mathrm{ul}$ of $10 \mathrm{xPCR}$ buffer, $1.0 \mathrm{ul}$ of $25 \mathrm{Mm} \mathrm{Mgcl} 2,1.0 \mathrm{ul}$ of $5 \mathrm{pMol}$ forward primer and $1.0 \mathrm{ul}$ of $5 \mathrm{pMol}$ forward primer (Table 1). Also added were 1.0 ul DMSO, 2.0 ul of 2.5Mm DNTPs, 0.1 ul Taq 5u/ul, $3.0 \mathrm{ul}$ of $10 \mathrm{ng} / \mathrm{ul}$ DNA and 13.4 ul water. A touch down PCR condition as earlier described by Agaviezor et al. (2018) was used PCR amplicons were sent to the International Institute of Tropical Agriculture, Ibadan for sequencing.

\footnotetext{
Table 1: Polymerase chain reaction primers for the amplification of the 2exons in the gene encoding the motilin receptor

\begin{tabular}{lllc}
\hline Primers & Forward primer $\left(\mathbf{5}^{\prime} \rightarrow \mathbf{3}^{\prime}\right)$ & Reverse primer $\left(\mathbf{5}^{\prime} \rightarrow \mathbf{3}^{\prime}\right)$ & Denaturizing temp $\left({ }^{\mathbf{0}} \mathbf{C}\right)$ \\
\hline Motilin 2 & CCAGACCTATACT T ATG & GATGACGTAAATACGAT & 93.4
\end{tabular}

\section{Statistical analyses}

The DNA sequences were aligned using Mega 6.0. Single Nucleotide Polymorphism and other sequence variation parameters were determined using Mega 6.0 (Tamura et al., 2013) and DNAsp version 5 (Rozas et al., 2003) and GENEPOP software package (Raymond and Rousset, 1995). The estimates of evolutionary divergence between

sequences were conducted using the Maximum Composite Likelihood model (Tamura et al., 2004). The analysis involved 3 nucleotide sequences. Codon positions included were $1 \mathrm{st}+2 \mathrm{nd}+3 \mathrm{rd}+$ Noncoding. All positions containing gaps and missing data were eliminated (Tamura et al., 2013). Significant associations were analyzed using SPSS (Statistical Package for Social Sciences) version 16.
} 


\section{Genetic diversity and association of motilin receptor gene between growth traits}

\section{Results}

The effects of motilin gene haplotypes on feed intake, feed conversion and body weight of Nigerian local chicken are depicted in Table 2. The result showed that there was no significant $(\mathrm{p}>0.05)$ difference between the haplotypes ( $\mathrm{CC}$ and $\mathrm{CG}$ ) in Feed intake. However, significant effects $(p<0.05)$ were observed for feed conversion ratio and body weight. The CG haplotype (mutant gene) recorded the numerical highest value $(3584.00 \pm 11.96 \mathrm{~g})$ in feed intake while the best feed conversion ratio (4.17 \pm 0.09$)$ was observed in CG haplotpes (mutant gene). Also, the body weight varied significantly $(\mathrm{p}<0.05)$ across the haplotypes studied. The CG (mutant gene) genotype recorded the mean weight of $1954.00 \pm 29.45 \mathrm{~g}$ which is higher than that recorded by CC $(1672.00 \pm 32.93 \mathrm{~g})$.

Table 2: Effect of motilin gene haplotypes on feed intake, feed conversation and body weight of Nigerian local chicken breeds

\begin{tabular}{llll}
\hline Haplotypes & Feed intake $(\mathrm{g})$ & Feed Conversion Ratio & Body weight $(\mathrm{g})$ \\
\hline CC (Normal gene) & $3558.00 \pm 13.37$ & $4.22 \pm 0.11^{\mathrm{a}}$ & $1672.00 \pm 32.93^{\mathrm{b}}$ \\
CG (Mutant gene) & $3584.00 \pm 11.96$ & $4.17 \pm 0.09^{\mathrm{b}}$ & $1954.00 \pm 29.45^{\mathrm{a}}$ \\
\hline
\end{tabular}

$a, b$ : Means within each column with different superscript differs significantly $(p<0.05)$

The interactive effect of breed and haplotype on feed intake, feed conversion ratio and body weight of Nigerian local chicken breeds is presented in Table 3. Although significant interactive effects were not observed $(p>0.05)$ between breed and motilin gene haplotypes, numerical changes were observed. Haplotype CC recorded the highest value of $3617.20 \pm 11.50 \mathrm{~g}$ in feed intake in Normal chicken breed, while the least feed intake $(3507.00 \pm 0.00 \mathrm{~g})$ was observed in $\mathrm{CC}$ haplotypes among Frizzle feathered chickens. The same result was observed in CG haplotypes where Normal feathered chickens had the highest feed intake

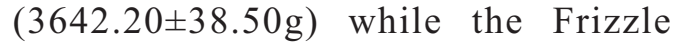
Chicken breed recorded the least value of $3553.00 \pm 74.95 \mathrm{~g}$ for feed intake compared to Naked Neck chicken breed with the value of $3557.00 \pm 0.00 \mathrm{~g}$. There was no significant $(p>0.05)$ interactive effect of breed and haplotype on feed conversion ratio across the chicken breeds studied. However, numerical variations were observed with the highest feed conversion ratio (4.69 \pm 0.43 ) been observed in CG (mutant gene) haplotypes among Frizzle feathered chickens while the lowest feed conversion ratio (3.68 \pm 0.00$)$ was observed also in CG (Mutant gene) haplotype among the Naked Neck chicken breeds. In addition, there was no significant $(p>0.05)$ interactive effect of chicken breed and haplotype on the body weight of chickens. However, numerical variations were observed. The higher weight of $2137.20 \pm 103.45 \mathrm{~g}$ was observed among the CG (Mutant gene) in Naked Neck chickens while the least interactive body weight $(1264.50 \pm 50.20 \mathrm{~g})$ was observed in CC (Normal gene) among the Frizzle feathered chickens

Table 3: Interactive effect of breed and motilin gene haplotype on feed intake, feed co nversion and body weight of Nigerian local chicken breeds

\begin{tabular}{lllll}
\hline Breed & Haplotype & Feed Intake & Feed Conversion Ratio & Body Weight \\
\hline Normal feathered & CC (Normal gene) & $3617.20 \pm 11.50$ & $4.28 \pm 0.48$ & $1898.20 \pm 57.72$ \\
& CG (Mutant gene) & $3642.20 \pm 38.50$ & $4.15 \pm 0.23$ & $2055.50 \pm 64.76$ \\
Frizzle feathered & CC (Normal gene) & $3507.00 \pm 0.00$ & $4.38 \pm 0.00$ & $1264.50 \pm 50.20$ \\
& CG (Mutant gene) & $3553.00 \pm 74.95$ & $4.69 \pm 0.43$ & $1670.00 \pm 179.60$ \\
Naked Neck & CC (Normal gene) & $3550.00 \pm 70.71$ & $4.00 \pm 0.00$ & $1854.00 \pm 65.05$ \\
& CG (Mutant gene) & $3557.00 \pm 0.00$ & $3.68 \pm 0.00$ & $2137.20 \pm 103.45$ \\
\hline
\end{tabular}




\section{Gunn, Chimenem-Amadi, Oleforuh-Okoleh and Agaviezor}

The effects of motilin gene haplotypes on growth performance data of Nigerian local chicken are shown in Table 4. Result showed that there was no significant $(\mathrm{p}>0.05)$ difference between the haplotype $\mathrm{CC}$ (normal) and haplotype CG (mutant) in wing length, shank length, drumstick, body length, height at wither and breast girth in this study. Haplotypes CG (mutant) shows a higher numerical values in wing length $(26.66 \mathrm{~cm})$, shank length $(11.91 \mathrm{~cm})$, drumstick $(16.04 \mathrm{~cm})$, body length $(46.41 \mathrm{~cm})$, height at withers $(46.20 \mathrm{~cm})$ and breast girth $(30.83 \mathrm{~cm})$ than the $\mathrm{CC}$ (normal) haplotypes, although not significant $(\mathrm{p}>0.05)$.

Table 4: Effect of motilin gene haplotype on the growth performance data of Nigerian local chicken breeds

\begin{tabular}{lllllll}
\hline Haplotype & $\begin{array}{l}\text { Wing length } \\
(\mathbf{c m})\end{array}$ & $\begin{array}{l}\text { Shank length } \\
(\mathbf{c m})\end{array}$ & $\begin{array}{l}\text { Drumstick } \\
(\mathbf{c m})\end{array}$ & Body length $(\mathbf{c m})$ Height at withers & $\begin{array}{l}\text { Breast girth } \\
(\mathbf{c m})\end{array}$ \\
\hline CC (Normal) & 25.50 & 11.87 & 15.50 & 46.00 & 44.58 & 29.75 \\
CG (Mutant) & 26.66 & 11.91 & 16.04 & 46.41 & 46.20 & 30.83 \\
SEM & 0.70 & 0.50 & 0.85 & 1.47 & 1.51 & 1.25 \\
\hline
\end{tabular}

The interactive effect of breed and motilin gene haplotype on growth performance data of Nigerian local chicken breeds are presented in Table 5. Result depicted that no significant differences $(\mathrm{P}>0.05)$ existed between interactive effect of breed and motilin gene haplotype among the growth parameters studied. However, numerical variations in value of parameters were observed. Haplotype CG (mutant) in normal feathered chickens recorded higher values in growth performance (wing length, shank length, drumstick, body length, height at withers and breast girth) compared with the haplotype CC (normal) counterpart of the same breed. Haplotype CC (normal) showed more superiority than haplotype CG counterpart in shank length (11.50), body length (47.00) and breast girth (29.50) although no significant difference $(\mathrm{p}>0.05)$ were observed. Haplotypes CG (mutant) in naked neck chickens shows a higher numerical difference in shank length (13.12), drumstick (17.37), height at withers (48.87) and breast girth (34.25) than the haplotypes CC (normal) counterpart of the same breed. The highest numerical value of wing length $(27.50 \mathrm{~cm})$ was observed CG (Mutant) haplotype among Normal feathered chickens while the lowest $(24.25 \mathrm{~cm})$ was seen in CC (Normal) haplotype also among Normal feathered chickens. For shank length, the highest value $(13.12 \mathrm{~cm})$ was observed in CG (Mutant) haplotype among Naked neck chickens and the least value was observed in CG (Mutant) among Frizzle feathered chickens $(11.00 \mathrm{~cm})$. More so, the highest drumstick $(17.37 \mathrm{~cm})$ was observed in CG (Mutant) among the Naked neck chickens and the least $(14.75 \mathrm{cmS})$ in CC (Normal) in Normal and Frizzle feathered chickens. Body length was highest $(48.00 \mathrm{~cm})$ in CC (Normal) among Naked neck chickens and least $(43.00 \mathrm{~cm})$ in $\mathrm{CC}$ (Normal) among Normal feathered chickens. Also, the highest value of height at withers $(48.87 \mathrm{~cm})$ was observed in CG (Mutant) among Naked neck chickens and the least $(41.25 \mathrm{~cm})$ in CC (Normal) among Normal feathered chickens. For breast girth, the highest value $(34.25 \mathrm{~cm})$ was in CG (Mutant) among Naked neck chickens and the least in CG (Mutant) among Frizzle feathered chickens $(28.00 \mathrm{~cm})$. 
Genetic diversity and association of motilin receptor gene between growth traits

Table 5: Interactive effect of breed and motilin gene haplotype on the growth performance data of Nigerian local chicken breeds

\begin{tabular}{|c|c|c|c|c|c|c|c|}
\hline Breed & Haplotype & $\begin{array}{l}\text { Wing } \\
\text { length } \\
\text { (cm) }\end{array}$ & $\begin{array}{l}\text { Shank } \\
\text { length } \\
\text { (cm) }\end{array}$ & $\begin{array}{l}\text { Drumstick } \\
\text { (cm) }\end{array}$ & $\begin{array}{l}\text { Body } \\
\text { length } \\
\text { (cm) } \\
\end{array}$ & $\begin{array}{l}\text { Height at } \\
\text { withers }(\mathrm{cm})\end{array}$ & $\begin{array}{l}\text { Breast } \\
\text { girth }(\mathrm{cm})\end{array}$ \\
\hline \multirow[t]{2}{*}{ Normal feathered } & CC (Normal) & 24.25 & 11.37 & 14.75 & 43.00 & 41.25 & 29.50 \\
\hline & CG (Mutant) & 27.50 & 11.62 & 15.50 & 45.87 & 43.25 & 30.25 \\
\hline \multirow[t]{2}{*}{ Frizzle feathered } & CC (Normal) & 25.00 & 11.50 & 14.75 & 47.00 & 45.50 & 29.50 \\
\hline & CG (Mutant) & 25.50 & 11.00 & 15.25 & 46.00 & 46.50 & 28.00 \\
\hline \multirow[t]{2}{*}{ Naked neck } & CC (Normal) & 27.25 & 12.75 & 17.00 & 48.00 & 47.00 & 30.25 \\
\hline & CG (Mutant) & 27.00 & 13.12 & 17.37 & 47.37 & 48.87 & 34.25 \\
\hline $\begin{array}{lllll}1 & 2 & 3 & 4 & 5 \\
\end{array}$ & $\begin{array}{lllll}6 & 7 & 8 & 9 & 10 \\
\end{array}$ & $\begin{array}{lll}12 & 13 & 1 \\
\end{array}$ & $15 \quad 16$ & $\begin{array}{lll}19 & 20 \quad 21 \\
\end{array}$ & 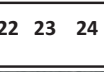 & 2526 & \\
\hline$x^{2}-4 x$ & Exis? & & & & 34 & 27 r & \\
\hline & & & 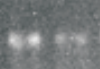 & & & 18 & 644 bp \\
\hline
\end{tabular}

Figure 1: Gel picture showing Polymerase Chain Reaction (PCR) products of motilin receptor gene in some chicken samples $(2-26) .1$ is 100 bp DNA ladder

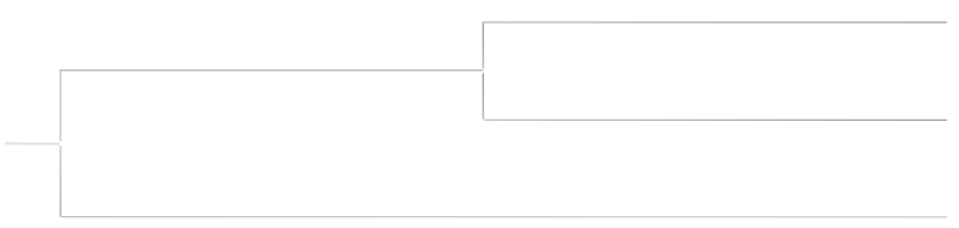

Normal

Frizzle

Naked Neck

\section{$\begin{array}{lllll}0.020 & 0.015 & 0.010 & 0.005 & 0.000\end{array}$}

Figure 2: Phylogenic tree using unweighted pair group method with arithmetic mean (UPGMA) between chicken breeds used in this study

The estimates of evolutionary divergence between sequences are shown in Table 6 . The highest estimates of evolutionary divergence between sequences (0.046) were observed between Naked neck chickens and Normal feathered chickens. This was followed by the distance $(0.034)$ between Naked neck and Frizzle while the least evolutionary divergence $(0.021)$ was observed between Normal feathered and Frizzle feathered chickens 
Gunn, Chimenem-Amadi, Oleforuh-Okoleh and Agaviezor

Table 6: Estimates of evolutionary divergence between sequences

\begin{tabular}{llll}
\hline & Normal feathered & Frizzle feathered & Naked Neck feathered \\
\hline Normal feathered & 1 & & \\
Frizzle feathered & 0.021 & 1 & 1 \\
Naked Neck & 0.046 & 0.034 & 1 \\
\hline
\end{tabular}

The result of within mean group genetic distance among Nigerian local chicken breeds is shown in Table 7. It was observed that distance varied across breeds. Normal

Table 7: Within mean group distance

\begin{tabular}{ll}
\hline Breed & Distance \\
\hline Normal & 0.143 \\
Frizzle & 0.026 \\
Naked Neck & 0.030 \\
\hline
\end{tabular}

\section{Discussion}

Feed intake was not affected by Motilin receptor gene haplotypes in this study. This implies that feed intake is not genetically influenced. However, the variation in feed conversion ratio and body weight across Motilin receptor gene haplotypes implies that the feed intake and body weight of the birds are genetically influenced. This result is supported by Zhang et al. (2011) who suggested that two SNPs of RB1gene they observed in their work might be quantitative trait nucleotides for body weight. However, they have not proposed any hypothetical mechanisms why the SNPs affect body weight (Takahashi et al., 2014). This result could be unconnected to that earlier report that Motilin binding sites are present in the gastrointestinal tract and central nervous system, along with a G-protein-coupled receptor, GPR38, which has been identified as motilin receptor gene (Feighner et al., 1999). There was also no significant ( $p>0.05$ ) effect of haplotype in wing length, shank length, drumstick, body length, height at withers and breast girth in this study. Furthermore, the study also revealed no significant differences ( $\mathrm{p}>0.05)$ existed between interactive effect of breed and motilin gene haplotype among the growth traits. Takahashi et al. (2014) had explained that the association between haplotypes and growth traits cannot be explained by the feathered chicken had the highest within mean group genetic distance (0.143). This was followed by Naked neck chicken (0.030), while Frizzle feathered recorded the least (0.026).

protein sequences, since the SNPs they detected in the coding regions of motilin receptor gene did not induce missense mutations, and thus motilin receptor proteins are functionally normal. The result of this study also supports the report Agaviezor and Uzoka (2020) in their work on the variation in melanocortin-4 receptor (MC4R) gene sequences in some poultry species. This was further supported by Agaviezor et al (2020) when they worked on the association between pituitary specific transcription factor 1 gene (PIT 1) and some carcass traits in Sasso and Shika brown chickens. The highest estimates of evolutionary divergence between sequences were observed between Naked neck chickens and Normal feathered chickens. This shows that crosses between both breeds will be more heterozygous thereby leading to more hybrid vigour. It was observed that genetic distance varied across breeds. Normal feathered chicken had the highest within mean group genetic distance. This implies that the normal feathered chicken is more variable for genetic improvement. Agaviezor and Chukwuemeka (2020) on their work on genetic diversity of pituitary transcription factor 1 (PIT 1) gene in Nigerian local and exotic chicken observed that the highest genetic distance was between Isa brown and Naked neck and the least between Naked 


\section{Genetic diversity and association of motilin receptor gene between growth traits}

neck and Shika brown. A similar report was also made by Niknafs et al. (2013) who studied SNPs in BMPR-IB and STAT5B genes and their association with growth and reproductive traits in chicken. Phylogenic trees are used for showing the genetic relatedness between species. It is used to show the evolutionary relationship between difference species as they emerge in different tine durations. This study clearly revealed that normal feathered and frizzle feathered chickens were more closely related than the naked neck chicken although they share common ancestry. The genetic element of both the normal and frizzle feathered chicken shared a common internal point. However, the genetic element of the naked neck chicken is distantly related to the normal and frizzle feathered chickens. The result from the phylogenic tree showed that there was a relationship between the normal feathered, frizzle feathered and naked neck chicken and large number of alleles were present at naked neck terminal point which signified that there was probably a long term evolutionary tenacity at the locus. This is related to the frequency as well as the allele in one species is closely related to more closely related specie than to other alleles of the same specie (Takeshima et al. 2008). A similar report has been documented by Sena et al. (2011) stating that cattle and water buffalo share common ancestry due to arrangement of their DQB region. According to Adebambo et al. (2009) there was no significant variation in genetic distances among the southwest, northwest and Northeast zone of the Nigerian indigenous chickens. However, the high genetic diversity observed in naked neck among the population studied may suggest that naked neck breed can be used for long term genetic development and breed stabilization.

\section{Conclusion}

The study on genetic diversity and association of motilin receptor gene between growth traits in Nigerian improved native chickens revealed that the highest estimates of evolutionary divergence using the motilin receptor gene was between Naked neck chickens and Normal feathered chickens. Also, motilin receptor gene was 11 associated with body weight and feed conversion ratio and not with other growth traits in Nigerian native chickens. The information provided here will assist in further improvement studies and programmes for the Nigerian native chicken breeds.

\section{References}

Adebambo, A. O., Mwacharo, J. M. and H a n n o t e, O. 2009. Characterization of Nigeria indigenous chicken ecotypes using microsatellite markers . Proceedings of the 3rd Nigeria International Poultry Summit, Feb. 22-26, SI, Ola., pp: 84-91

Agaviezor, B. O. and Chukwuemeka, C. S. 2020. Genetic diversity of pituitary transcription factor 1 (PIT 1) gene in Nigerian local and exotic chicken, Nigerian Journal of Animal Production 47(1):12-18

Agaviezor, B. O. and Uzoka, O. N. 2020. Variation in melanocortin-4 receptor (MC4R) gene sequences in some poultry species, Delta Agriculturist 12(1):67-72

Agaviezor, B. O., Ajayi, F. O. and Nwachukwu, C. C. 2018. Association between chicken growth hormone gene and growth performance in chickens raised in South-South Nigeria, African Journal of Agriculture, Technology and Environment 7(2):188 - 194

Agaviezor, B.O., Ajayi, F.O. and Udoudo, O. A. 2020. Association between pituitary specific transcription factor 1 gene (PIT 1) and some 
carcass traits in Sasso and Shika brown chickens, Journal of Bioscience and Agriculture Research, 23(02): 1937-1943

Gondwe, T. N. and Wollny, C. B. A. 2005. Evaluation of the growth potential of local chickens in Malawi. International Journal of Poultry Science 4(2): 64-70

Kitazawa, T., Yoshida, A., Tamano, T., Teraoka, H. and Kaiya, H. 2013. "Age-dependent Reduction of Ghrelin - and Motilin-induced Contractile Activity in the Chicken Gastrointestinal Tract." Peptides 43: 88-95.

Niknafs, S., Javaremi, A. N. and Sadeghi, M. 2013. Single nucleotide polymorphism in BMPR-IB and STAT5B genes and their Association with growth and reproductive traits in chicken. Songklanakarin Journal of Science and Technology, 36(2), 137-142.

Ohshiro, H., Nonaka, M. and Ichikawa, K. 2008. "Molecular Identification and Characterization of the Dog Motilin Receptor." Regulatory Peptides 146: 80-87.

Ramlah A. H. 2005. The Scope and Effect of Family Poultry Research and Development. Production aspects of village chicken in the SouthEast Asian Region. FAO 12653

Raymond, M. and Rousset, F. 1995. GENEPOP (version 1.2): Population genetics software for exact tests and ecumenicism. $J$. Hered. 86:248-249.

Rikimaru, K., Takahashi, H. and Nichols, M. A. 2011. An efficient method of early aponization in slow-growing meat-type chickens. Poultry Science 90: 1852-1857.

Rosenfeld, D.J. and Garthwaite, T.L. 1987. Central administration of motilin stimulates feeding in rats.
Physiol Behav. 39:753-756.

Rozas, J., Sanchez-DelBarrio, J.C., Messeguer, $X$. and Rozas, $R$. 2003. DnaSP, DNA polymorphism analyses by the coalescent and other methods. Bioinformatics. 19:2496-2497

Sena, L., Schneider, M.P.C., Brenig, B.B., Honeycutt, R.L., Honeycutt, D.A., Womack, J.E. and Skow, L.C. 2011. Polymorphism and gene organization of water buffalo MHC-DQB genes show homology to the BoLA DQB region. Anim Genet 42:378-385

Takahashi, H., Rikimaru, K., Komatsu, M., Uemoto, Y. and Suzuki, K. 2014. "Association between Motilin Receptor Gene Haplotypes and Growth Traits in Japanese Hinai-dori Crossbred Chickens." Asian-Australasian Journal of Animal Sciences 27: 316-323.

Takeshima, S., Chen, S., Miki, M., Kado, M. and Aida, Y. 2008. Distribution and origin of bovine major histocompatibility complex class II DQA1 genes in Japan. Tissue Antigens 72:195-205

Tamura, K., Nei, M., and Kumar, S. 2004. Prospects for inferring very large phylogenies by using the neighborjoining method. Proceedings of the National Academy of Sciences (USA) 101:11030-11035.

Tamura, K., Stecher, G., Peterson, D., Filipski, A., and Kumar, S. 2013. MEGA 6: Molecular Evolutionary Genetics Analysis version 6.0. Molecular Biology and Evolution 30:2725-2729.

Trudel, L., Tomasetto, C., Rio, M. C., Bouin, M., Plourde, V., Eberling, P. and Poitras, P. 2002 . "Ghrelin/motilin-related Peptide Is a Potent Prokinetic to Reverse Gastric Postoperative Ileus in Rat." 
Genetic diversity and association of motilin receptor gene between growth traits

American Journal of Physiology-

Gastrointestinal and Liver

Physiology 282: G948-G952.

Yamamoto, I., Kaiya, H., Tsutsui, C., Sakai, T., Tsukada, A., Miyazato, M. and Tanakae, M. 2008). "Primary Structure, Tissue Distribution, and Biological Activity of Chicken Motilin Receptor." General and Comparative Endocrinology 156: 509-514

Received: $21^{\text {st }}$ December, 2020

Accepted: $26^{\text {th }}$ February, 2021 